\title{
COMPENSATION FOR SURFACE RIGHTS IN ALBERTA
}

\author{
J. DARRYL CARTER \\ COLIN CARTER \\ ROY CARTER*
}

\begin{abstract}
The authors advocates a new method of assessing compensation under the Alberta Surface Rights Act. This method, termed the "global approach" has found acceptance in the courts, as it has been difficult to give fair awards only using the heads of damages listed in the Surface Rights Act. The authors explain these difficulties and the advantages of the "global approach".
\end{abstract}

\section{INTRODUCTION}

Much of the Canadian jurisprudence dealing with compensation for surface rights is found in the Province of Alberta because of the extensive involvement of the oil industry which frequently requires portions of privately owned land for wellsite locations and pipelines.

The Alberta Surface Rights Act ${ }^{1}$ provides in 25(1):

The Board, in determining compensation payable, may consider

(a) the amount the land granted to the operator might be expected to realize if sold in the open market by a willing seller to a willing buyer on the date the right of entry order was made,

(b) the per acre value, on the date the right of entry order was made, of the titled unit in which the land granted to the operator is located, based on the highest approved use of the land,

(c) the loss of use by the owner or occupant of the area granted to the operator,

(d) the adverse effect of the area granted to the operator on the remaining land of the owner or occupant and the nuisance, inconvenience and noise that might be caused by or arise from or in connection with the operations of the operator,

(e) the damage to the land in the area granted to the operator that might be caused by the operations of the operator, and

(f) any other factors that the Board considers proper under the circumstances.

There are two entirely different approaches, however, which the Surface Rights Board has used in determining compensation. The traditional approach was the "four heads" method, which assumed that compensation could be calculated under four distinct heads, namely:

(a) value of land;

(b) general disturbance;

(c) loss of use; and

(d) adverse effect.

More recently, however, the courts and some members of the board have recognized that there are more factors to be considered. Further, because compensation for each factor cannot be computed mathematically, it is better to make a global award for all of the rights that have been taken from the landowner. This "global" approach was first expressed in Eastman v. PanCanadian ${ }^{2}$ where MacLean J. referred to his assessment of compensation, and stated:

- Darryl and Roy Carter are partners in the law firm of Carter, Lock \& Repka, Grande Prairie, Alberta. Colin Carter is an Associate Professor in the Department of Agriculture Economics and Farm Management at the University of Manitoba.

1. 1983, S.A., c. S-27.1.

2. Unreported, 05 March 1982, J.D. of Medicine Hat, Q.B. 8208-0017. 
It is difficult to split that figure and alot it in various proportions. The practice both in the Surface Rights decisions and in the decisions of this Court, has been to allocate specific amounts to the various factors set out in Section 23(2) of the Surface Rights Act, but allocation, in my mind, is not necessarily required under the Act. All that is required is that the Court consider the various factors that are set out under that Act.

1 am satisfied that the evidence in this particular case supports the fact or supports the proposition that it is the total figure, the end figure, that is important not just to the oil company operator, but to the landowner as well; and that the breakdown of the figure is a matter that the landowner is perfectly prepared to leave to the discretion of the operator oil company. 1 would think that the reasonable inference that should be drawn from that kind of an approach is that the oil company, the operators at least, are aware of the factors to be considered and have considered them in ariving at the global lump sum, a single figure; and the farmer-owner, on the other hand, although he might not be aware of the particular provisions of the Act, is aware of the kind of things that he should address his mind to so that he can arrive at his overall compensation. Again, that is the end figure that they are both interested in.

In Amoco Canada Petroleum Co. Ltd. v. Schwartz, McDonald J. stated: ${ }^{3}$

I too do not feel it necessary to assign a monetary figure for each individual item, but I am prepared to do so for what it is worth. As I say, I believe a global figure is sufficient and satisfactory, but that does not mean that breaking it down would be improper and it may be helpful to the parties.

A comparison of certain cases demonstrates how far apart the results of the two methods (four heads vs. global) can be. In Petryshen v. Nova, An Alberta Corporation ${ }^{4}$ the court, using the global approach, awarded landowners in the Grande Prairie area compensation for a pipeline which amounted to double the appraiser's market value of the land. However, in another case heard in Red Deer at approximately the same time, Dome Petroleum Ltd. v. Liivam Farms Ltd., " the court using the "four heads" method awarded compensation at twenty-five per cent of the appraiser's market value. As a result, there was an eightfold difference in compensation relative to market value between these two decisions.

In another Red Deer case, Gulf Canada Resources Inc. v. Moore, ${ }^{6}$ the landowner was awarded only fifty per cent of the market value. The operator's appraiser had actually calculated the value of the easement area to be less than the residual and reversionary value to the landowner. The landowner, therefore, would have owed money to the operator! Holmes J. resolved the problem by stating: ${ }^{7}$

However, counsel for the appellant conceded that in the circumstances 50 per cent of the en bloc value would be realistic and appropriate. I concur and the board's award will be varied accordingly.

In ef fect, the operator's lawyer determined the amount of compensation. However, when Holmes J. heard a number of cases relating to the same pipeline as in Petryshen, he upheld the board's decision which had allowed compensation amounting to double the en bloc value: Nova, An

3. Unreported, 24 January 1984, J.D. of Wetaskiwin, Q.B. 8212-00553 at 3.

4. (1983) 23 Alta. L.R. (2d) 193, 27 L.C.R. 276.

5. (1983) 26 L.C.R. 9.

6. (1983) 22 Alta. L.R. (2d) 328.

7. Id. at 335 . 
Alberta Corporation v. Bain. ${ }^{8}$ His decision was subsequently upheld by the Court of Appeal. ${ }^{9}$ Holmes J. approved of the board's use of a global award saying: ${ }^{10}$

The board assessed those intangible items in arriving at its award of $\$ 950.00$ per acre. It preferred to make an inclusive or global award since separate compensation under each of those heads is very difficult, if not impossible, to quantify with any degree of precision.

The global approach is preferable because it avoids the many problems inherent in the four heads approach.

\section{THE PROBLEMS WITH THE FOUR HEADS APPROACH}

\section{A. IT ASSUMES THAT COMPENSATION CAN BE \\ SEGREGATED INTO FOUR SEPARATE CATEGORIES WHICH CAN BE MATHEMATICALLY CALCULATED AND ADDED UP TO GIVE A TOTAL AWARD.}

It is not possible to segregate compensation for a right of entry order into distinct categories. The Court of Appeal in Nova v. Will Farms Ltd." found how easy it was to "slip from one head of compensation to another". The factors to be considered (and there are certainly more than just four) are all interrelated. How, for example, can damage, loss of use, inconvenience, nuisance, general disturbance or adverse effect be separated from each other? The property rights being affected are not absolute "things" for which values are readily measureable. There is, of course, no market for each individual "head" and thus no easy way of pricing them separately. As will be discussed later, however, there is a market of sorts for the whole bundle of rights as evidenced by agreements between operators and landowners.

The courts have often calculated compensation under the four heads simply because of the way the case was presented to them. When, however, they have actually examined the process of determining compensation they have rejected the mathematical approach.

In Roen v. PanCanadian Petroleum, Medhurst J. stated:12

The task of determining compensation is very difficult. It involves calculating a sum that should be paid for the use of a small parcel that comprises part of a larger area. Some of the factors that may be considered in arriving at the compensation to be paid are set out in s. 23(2). These factors are not all-inclusive as provision is also made for consideration of such other factors that may be considered proper under the circumstances.

The problem involved is acknowledged to be difficult and the following statement from the Supreine Court of Canada in Lacoste et alv. Cedars Rapids Mfg. \& Power Co. [1928] 2 D.L.R. 1, 47 Que. K.B. 271 at p. 285, 34 C.R.C. 399, is often quoted in cases such as this, where it is stated: "the proper amount to be awarded in such a case cannot be fixed with mathematical certainty but must be largely a matter of conjecture".

8. (1984) 33 Alta. L.R. (2d) 187, 31 L.C.R. 47.

9. Unreported, 11 January 1985, J.D. of Edmonton, C.A. 17757.

10. Supra n. 8 at 53.

11. [1981] 5 W.W.R. 617 at 619 .

12. (1978) 12 L.C.R. 143 at 147. 
The mathematical four heads approach tends to down-play the importance of intangible losses because they are difficult to evaluate. Since only four factors are looked at, many of these intangibles are ignored altogether and others are assigned only nominal amounts.

\section{B. IT ASSUMES THAT COMPENSATION IS BASED PRIMARILY ON THE VALUE OF THE LAND.}

The premise seems to be that awarding an amount equal to the average per acre value of the land affected by the right of entry order will result in full compensation to the landowner. This is no more accurate than it would be to suggest that compensation for taking three square feet from the living room of a house worth an average of $\$ 50.00$ per square foot should be $3 \times \$ 50.00=\$ 150.00$.

There has been an over-emphasis, almost a fixation, with the value of the land in surface rights cases which has lead to many problems:

1. Shouldn't there be a deduction for the residual or reversionary interest? See Cochin Pipe Lines Ltd. v. Rattray, ${ }^{13}$ Dome Petroleum Ltd. v. Liivam Farms, ${ }^{14}$ Gulf v. Moore, ${ }^{15}$ Dome Petroleum Ltd. v. Fead, ${ }^{16}$ and Dome Petroleum Ltd. v. Grekul. ${ }^{17}$

2. How can you award compensation for a second pipeline on the same right of way? See Nova v. Will Farms Ltd. ${ }^{18}$

3. How can you justify an annual rental without giving double compensation? See Eden Gas Company Ltd. v. Klaiber. ${ }^{19}$

The cases have often failed to appreciate what is actually being exchanged. It is not land being exchanged, but rather the landowner's surface rights. This exchange involves a benefit to the operator and a cost to the landowner. The board falls into the trap of trying to value the basic resource (i.e. land) rather than the rights. This is a common mistake. ${ }^{20}$ Instead of the value of the land, the issue should be what is the value to the owner of what is being taken from him. In Diggon-Hibben Limited v. His Majesty the King, the Supreme Court of Canada stated:21

It is the value to the owner and not the market value to the purchaser that must be determined. In the determination of that value to the owner various items may be considered and these will vary according to the circumstances of particular cases. The total of the items that may properly be taken into account determines the value to the owner. ${ }^{14}$

In the Rattray case, ${ }^{22}$ the Court of Appeal at page 200 expressly endorsed the decision of the learned arbitrator, that "general principles of

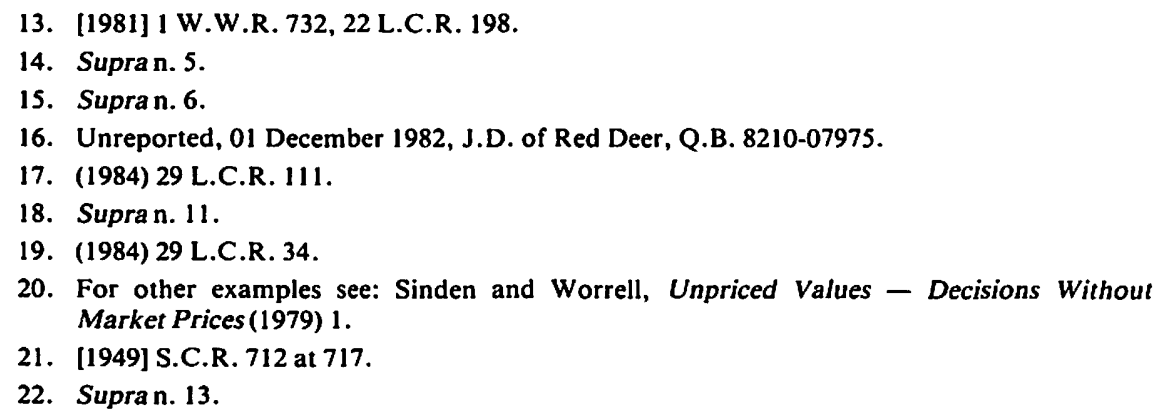


compensation require a tribunal to consider the value to the owner of what is taken'. [Emphasis added.]

The Rattray case, however, has often been used against landowners both before the board and before the courts because the discussion has been about the value of the land rather than the value of the rights taken. The argument in the Rattray case centered on the value of the land. Other factors such as damage, inconvenience, disturbance and adverse effect were not dealt with.

Rattray held that the residual interest of the landowner must be considered. This is correct, but many other factors must be considered as well. When these factors are taken in account, compensation may be much more than the average per acre land value.

In fact, it is arguable that the residual and reversionary interest could even be a liability in some cases. For example, if fee simple title to a strip along the edge of the owner's land is taken for a highway, he does not have to worry about it any more. However, if he retains ownership of the same strip subject to a pipeline or powerline right-of-way he still has to pay taxes on the land and look after it. The pipeline construction might have damaged the land so that there is no longer any profitability in farming it, but he will continue to do so primarily for weed control. He will also be faced with the prospect of the area over the line settling in the future, the risk of working over the pipeline and the possibility of the line being dug up again for maintenance. Similarly, in the case of the powerline, he will continue to farm the land for weed control but is subject to the risk associated with the line and the poles on the land. He might very well say that he would have rather not been burdened with the residual and reversionary interest.

The court in Rattray rejected the arbitrary "Blackstock formula" but adopted the equally arbitrary formula of Bonaventure Sales Ltd. v. The Queen, ${ }^{23}$ which held that the only method of arriving at the fair market value was to take a fair market value of the whole parcel and then attribute the per acre value to the acreage taken. Rattray could be distinguished on the grounds that it was not a case under the Surface Rights Act or on the grounds that it "turned on the particular facts of the case" (as Rattray itself distinguished Copithorne v. Shell ${ }^{24}$ and Lambv. Canadian Reserve Oil and Gas Ltd. ${ }^{25}$ ) The real distinction, however, is that it was only dealing with the value of the land.

The Bonaventure case, too, was only concerned with the proper method for assessing the fair market value of strips taken for a highway. Other issues such as damage, inconvenience or adverse effect were not considered because the strips were along the boundary of the land in question. If the highway had cut through the property diagonally, surely the compensation would not be based on the simple calculation of the average per acre value of the land multiplied by the number of acres taken.

23. (1981) 22 L.C.R. 164 .

24. (1969) 70 W.W.R. 410.

25. (1976) 4 W.W.R. 79. 
The Bonaventure decision was delivered by the Court from the bench without citing any authorities and is clearly a case which "turned on its own particular facts". Its application has already been limited in Kerr v. Minister of Transportation (No. 1). ${ }^{26}$ Bonaventure was decided shortly before Rattray, and the Court applied it in Rattray dealing only with the issue of the value of the land. We do not know, for example, if the pipeline in Rattray was along the boundary of the land or not.

The court in Rattray acknowledged that the proper consideration should be "the value to the owner of what is taken", but it never questioned the assumption that compensation for a pipeline right of way should be based directly on market value. The value to the owner of rights to a strip of land is not what he could sell the strip for (that would be the value to a purchaser), but rather what you would have to offer him to acquire his rights. This may mean having to of fer him much more than the average en bloc market value because of the many other factors involved. As the Court said in Bonaventure itself: "The strips should not be treated as something they are not". Therefore, a pipeline should be treated as a pipeline and not simply as an average portion of a quarter section. Similarily a wellsite should be treated as a wellsite and a powerline as a powerline.

The Bonaventure - Rattray en bloc market value approach was also used by the Court of Appeal in Patson Industries Ltd. v. City of Calgary 27 because no one questioned the appraiser on his use of this approach and the owner had failed to present any contrary evidence. The Court acknowledged that the result was contrary to "common experience" (i.e. contrary to common sense).

The operator in the Petryshen case relied on Bonaventure and Rattray, arguing that the average market value of the land (according to their appraiser), less the residual and reversionary value, should be the proper compensation. The landowners on the other hand did not dispute the market value, but successfully argued that they were talking about the value of a pipeline right-of-way, which is a different matter. The Court of Appeal in its decision did not refer to either the Bonaventure or the Rattray cases.

In the Saskatchewan case of City of Weyburn v. Giroux, ${ }^{28}$ Malone J. refused to follow the simplistic Bonaventure approach because it did not place enough emphasis on the value to the owner.

The Bonaventure-Rattray approach has also been expressly overruled by the new Surface Rights Act. Section 25 (1) (a) allows the board to consider the value of the small area covered by the right of entry order as well as the en bloc area of the whole parcel. Holmes J. in the Bain case based his decision, in part at least, on the fact that the new s. 25 was different that the old s. 23. It is noteworthy, however, that the court in the Petryshen case had reached the same conclusion under the old Act.

26. (1981) 22 L.C.R. 179.

27. (1984) 30 L.C.R. 190.

28. (1984) 29 L.C.R. 23. 
In Anderson Exploration Ltd. v. Dion, Bracco J. stated:29

\begin{abstract}
However, the "market" regarding the sale of farm land cannot be fairly compared to the situation here. In this case, the operator seeks to use a portion of the farmer's land for the purpose of drilling an oil well and the duration of such use may be brief or for an extended period of time. The consequences of such use is very different from a sale.
\end{abstract}

For a discussion of the difference between market value and the value to the owner see Knetsch and Borcherding, "Expropriation of Private Property and the Basis for Compensation". ${ }^{30}$ Richards and Price in their article "Surface Rights Acquisition and Compensation", 31 point out that the cases generally do not distinguish between market value and the value to the owner. Their discussion, however, deals with the value of the land rather than the value of what was taken.

The cases have failed to recognize that market prices of ten fall well short of the reservation value to the owner. ${ }^{32}$ The reservation price represents the value to the owner. Since the landowners are entitled to compensation based on the value to them, the reservation value would represent the minimum compensation required. The reservation value will be greater than the market value because the economic welfare suffered by landowners through loss of property rights is greater than the welfare obtained through the purchase of an alternative parcel (if such a purchase was even possible). For example, two parcels of land may well have equal market value according to appraisers but they are unlikely to be regarded as having equal value by two separate landowners. The difference between the reservation value and the market price will normally depend on such things as the proximity of the land to other holdings, total size of other holdings and the history of ownership. The value to the owner of a part of his holdings is greater than the value to him of a part of someone else's holdings.

The fixation with the value of the land has caused operators to believe that an offer for more than market value is a bonus. ${ }^{33}$ To consider that this is a bonus, however, is only looking at it from the operator's point of view. To the landowner, there is no bonus at all, because the value of the land is only one of the factors and, considering all of the factors, the total compensation due to him for what has been taken may be much more.

In Canadian Western Natural Gas Co. Ltd. v. Broomfield, ${ }^{34}$ the board had stated that they could not award more than 1,000 dollars per acre for a pipeline since that was the value of the land. On appeal, however Dea J. held that 1,500 dollars per acre was the proper compensation based on what the operator and other landowners had agreed to. See also Nova v. Bain, ${ }^{35}$ where the Court of Appeal upheld the board's award even though the per acre value of the land was "appreciably lower".

29. Unreported, 10 February 1984, J.D. of Peace River, Q.B. 8309-0968 at 5.

30. (1979) 29 U. of T.L.J. 237.

31. (1982) 20 Alta. L. Rev. I at 13-14.

32. See: Knetsch and Borcherding, supra n. 30.

33. See, for example, the discussion of the operator's evidence in Dome v. Fead, supra n. 16 at 5.

34. Unreported, 07 May 1984, J.D. of Fort MacLeod, Q.B. 8407-00064.

35. Supran. 8. 
We submit that it is clear from reading board and court decisions in surface rights matters that the four heads approach and particularly the reliance on the market value of the land has caused much of the difficulty. In Dome v. Fead, Miller J. referred to the difficulties inherent in decisions such as Gulf v. Moore, ${ }^{36}$ Dome v. Liivam Farms $L t d{ }^{37}$ and Nova v. Petryshen. ${ }^{38}$ With respect, however, we would suggest that the difficulties were only inherent in the Moore and Liivam cases because of the emphasis on the value of the land. There was no difficulty in the Petryshen case because the residual and reversionary interest had been considered in the total amount.

Since proper compensation is not directly related to the value of the land, there may also be cases where it is in fact lower. In Krupa v. Camel Resources Ltd., Wachowich J. stated: ${ }^{39}$

The extracted principle above cannot be taken to mean that if the board considers

"value of land", it must award that value in the owner's mind as compensation.

He upheld an award of 2,500 dollars per acre notwithstanding a market value of 14,000 dollars per acre.

Thus, compensation is not related directly to the "value of the land" even if appraisers could accurately calculate it.

\title{
C. IT ASSUMES THAT THE MARKET VALUE OF FARM LAND CAN BE ACCURATELY CALCULATED.
}

This assumption is wrong. Only a small percentage (less than five per cent) of all the farm land in the province changes hands in any one year. Yet "expert" appraisers say they can determine a market value for it. In fact, all they can provide is the price at which a few examples sold. This might be some indication of what a farmer could expect to receive for his land if he had to sell (a distress sale), but there is a big difference between a selling price and a buying price, i.e. what you would have to of fer the farmer in order to buy it (the value to the owner). Most farmers are not interested in selling at any price. They want to keep their land as an economic unit for themselves, their children and their grandchildren.

The farm land market is a classic example of a "thin" market because there are so few transactions in any given time period and many of the transactions that do take place are not at arm's length. A characteristic of a thin market is that price behavior during a given year is unwarranted by supply and demand. Prices in a thin market fluctuate widely and thus convey poor information about the true value of the asset.

Some members of the board recognized this in Dome v. Richards where they stated: 40

admittedly it is difficult to find reliable arm's length sales data for good productive land in any area of the Province. ...

\author{
36. Supran. 15. \\ 37. Supran. 5. \\ 38. Supran. 4. \\ 39. (1982) 26 L.C.R. 211 at 215. \\ 40. Decision No. $214 / 83$ at 4 (Sept. 30/83).
}


The reliance on market value has also resulted in the use of "average" rather than "marginal" value determinations. The Bonaventure-Rattray approach calculates value by taking an appraisal of a whole quartersection and dividing it by 160 i.e. the average per acre value. This ignores the fact that the landowner is entitled to compensation for a small number of acres which are normally marginal to the overall farming operation. Clearly, the marginal value can differ substantially from the average value. For example, a perfectly rational farmer may be quite willing to pay 10,000 dollars to clear and drain a five acre slough $(2,000$ dollars per acre) even though he would only pay 160,000 dollars for a quarter section (1,000 dollars per acre on average). He will pay the extra cost of bringing the slough into production because he looks at the marginal returns from cropping an additional five acres versus his marginal costs. Given that many of his costs of farming the first 155 acres are "sunk", the farmer reasons that the profit from planting five marginal acres will be high. Thus, the marginal value of the five acres from productive use is much greater than the average per acre value of the quarter section.

This was recognized in Whitehouse v. Sun Oil Ltd. ${ }^{41}$ where Stevenson J. stated that "the taking of a small site out of agricultural production is, to all intents and purposes, a loss of income, as the cost of maintaining a farming operation is not significantly reduced by the loss of that site".

In Nova v. Harding et al, the board stated:42

the prospect of a bumper crop in any year or perhaps even in successive years produces a value substantially higher than (the appraiser) Shaske's estimate of market value, since any yield increase is a clear net gain. It is that prospective view that makes land held in a bona fide farming operation unique and difficult to value by traditional methods employed by appraisers for properties which regularly trade in the market price.

And in Nova v. Jones et al the board stated: 43

In connection with the Operator's view that the market value of the land affected is the measure of compensation due, it is the Board's opinion that had the Legislature intended such a strict adherence to the market value of the land as the criterion for determining compensation for the taking, it would have said so as it did in The Expropriation Act. But it did not so legislate, and provided for consideration of other relevant factors. It provided for the broadest view of value as may be found in the circumstances.

\section{IT ASSUMES THAT YOU CAN REPLACE WHAT HAS BEEN TAKEN BY GOING TO THE "MARKET PLACE" AND PURCHASING IT WITH THE COMPENSATION.}

This assumption however, fails to take into account not only that farm land is generally not available for sale, but that you are dealing with an expropriation of rights that cannot be replaced in the market place. It is not like the expropriation of a house in the city, where the party being expropriated can take his compensation and buy a new house. A landowner does not have the option of taking the money which he receives from the operator and purchasing the rights which he has lost. The appraisers' principle of substitution simply does not apply. Furthermore, cases under

41. [1982] 6 W.W.R. 289 at 297.

42. Decision No. E 247/84 at 14 (Aug 23/84).

43. Decision No. E 253/84 at 11. 
the Surface Rights Act involve the taking of some rights and the leaving of some others with the owner (taking a bundle out of a larger bundle). Therefore, not only must we concern ourselves with the rights being taken, but also with the effect on the value of the remaining rights i.e. the adverse effect on the quiet enjoyment or marketability of the whole parcel.

\title{
E. IT ASSUMES THAT ONLY THE AREA COVERED BY THE RIGHT OF ENTRY ORDER IS AFFECTED.
}

This assumption ignores the fact that wellsites, pipelines or powerlines have an impact on the remaining land as well. Compensation for things such as smell, noise, dust, air quality or aesthetics is not directly related to the acreage included in the right of entry order. There should not be a fifty per cent difference in compensation between a wellsite of six acres and one of four acres, all other things being equal. Compare the taking of a six square foot piece out of your living room and a four square foot piece.

The taker's intended use is also an important consideration. Taking a portion of your front lawn for a flower garden is not the same as taking it for a telephone booth. Compensation, of course, is not for the value to the taker but rather the value to the owner of what is taken. What is taken is the owner's right to prevent that particular use.

\section{F. IT IGNORES THE DAMAGE TO THE LAND.}

The board, in many decisions, has ignored the damage to the land using the reasoning that the land will some day be reclaimed pursuant to the Land Surface Conservation and Reclamation Act. ${ }^{44}$ For example, in Texaco Canada Resources Ltd. v. Macklin, the Board stated:45

\begin{abstract}
The respondent appears to suggest that the Board is required by the Act to award compensation for damage to the land (s. $23(2)(d))$. That provision of the Act states that the Board "may consider (d) the damage to the land in the area granted", and the Board has found hereinbefore that the matter of physical damage falls to the jurisdiction of the Land Conservation and Reclamation Council at the time the operator proposes to abandon the site.
\end{abstract}

This approach is clearly contrary to $s .25$ which specifically refers to damage to the land. The damage in many cases can be greater than the appraiser's calculation of the average per acre market value.

In $R e$ Caswell and Alexandra Petroleums Ltd. ${ }^{46}$ the Court of Appeal said that the decision of the learned trial judge was wrong when:47

He stated that there was no evidence before him that this entire area would be damaged permanently and he particularly mentioned that the appellant "indicated" that the road was not to be gravelled and that the sump and mud pits might possibly lead to some permanent damage but this would only represent a small fraction of an acre. He also contended that land worth $\$ 50$ an acre (which was apparently the over-all valuation of the quarter section on which the site was located) could not be permanently damaged to the extent of $\$ 125$ an acre, and he referred to the provisions of the Surface Reclamation Act, 1963 (Alta.), c. 64 (now R.S.A. 1970, c. 356), which requires an operator when

44. 1980, R.S.A., c. L-3.

45. Board Decision No. E $133 / 80$ at 8.

46. (1972) 2 L.C.R. 299 (leave to appeal to S.C.C. dismissed, (1972) 3 L.C.R. 298).

47. Id. at 236. 
ordered by the Surface Reclamation Council thereby appointed so to do to take certain steps to clean up and reclaim areas used in its operations when these are terminated. He eliminated the award under this heading altogether.

In Palleyv. Sulpetro of Canada Ltd., Crossley J. stated:48

Some evidence was given as to the value of an acre of land in this particular area, but I do not think that is the only criteria. If a farmer intends to keep the land, as Mr. Palley has stated he wants to do, and if it will take some time for him to restore the land to a reasonable condition, then the compensation should not only be related to the maximum value of the land. I feel I have to be arbitrary in this regard, but $I$ am allowing the total value of the acreage to be raised to $\$ 900.00$ per acre making a total of $\$ 4,032.00$.

The Court of Appeal upheld Crossley J.'s decision, and stated:49

... the learned trial judge recognized that there is a difference between restoration and reclamation. The land may be reclaimed, but it may take several years of cultivation and fertilization to restore it to its previous state as first-class farm land.

The argument that compensation for damage to the land could not exceed the "market value" was also rejected by the Ontario High Court in Interprovincial Pipe Line Ltd. v. Lewington et al..$^{50}$

The importance of considering the damage to the land becomes apparent in cases dealing with "dry holes" because the land is acutally returned to the landowner. In Anderson Explorations Ltd. v. Dion, ${ }^{51}$ the Court had to assess compensation for a "dry hole". The operator relied on the Grekul case, ${ }^{52}$ which had held that compensation in such circumstances should be based on a calculation of twenty-five per cent of the land value. The landowner however introduced evidence of the long term damage to the land caused by a wellsite and the Court upheld the board's decision to award the same initial compensation for a dry hole as for a producer.

Bracco $\mathrm{J}$. held that the board was wrong in stating that no compensation was payable for damage to the land although he found that they had actually considered this "head" of damage in arriving at the total award.

In Mobile G.C. Canada Ltd. v. Fletcher, ${ }^{53}$ McDonald J. held that the appraiser had been in error when he "appear[ed] to express a view that compensation (for damage) should only be awarded only at the end of the lease". McDonald J. also stated that the question of compensation must be reviewed as a whole and he rejected the Grekul case's arbitrary formula for calculating residual and revisionary values. ${ }^{54}$

More recently, the board has been including a consideration of the damage to the land in its determination of compensation. For example, in PanCanadian Petroleum Ltd. v. Carter, it stated: ${ }^{55}$

In arriving at its decision on compensation, the Board finds the damage to the land is a factor which at least in part should be compensated for at this time.

48. (1983) 44 A.R. 59 at 62.

49. (1983) 44 A.R. 57 at 58; 27 L.C.R. 117 at 118.

50. (1982) 23 L.C.R. 122.

51. Supran. 29.

52. Supran. 17.

53. (1984) 30 L.C.R. 207 at 217.

54. Id. at 216-217. It is interesting to note the different approach that the same judge (Miller J.) took in the Grekulcase as compared to the Fead case.

55. Board Decision E 342/84 at 4. 


\section{And in Dome v. Heiken:56}

The Operator argues that the mere process of reclamation and the approval of that reclamation work will remedy any and all damage done to the land by the Operator's operations. That has not been the Board's experience in viewing reclaimed sites and hearing evidence on post-reclamation production. There is inevitably (with the possible exception of some areas with a super-abundance of topsoil) certain residual damage which even the most stringent and efficient reclamation methods can not remedy. Such damage will be exhibited in poorer growth and reduced yields over a relatively long term. The ef fect may or may not be discernable to the trained eye, but nevertheless the Board is satisfied from the nature of the damage done in such an operation as this that it is there, and that the loss is significant on the long term effect. Those anticipated losses, (which in the circumstances here are imminently expectable), must be looked at in compensation as damage to the land done or likely to be done by the operations. This will be considered in the Board's determination of compensation.

\section{THE GLOBAL AWARD}

If, however, the presentation to the board or the court is not limited to the four heads, a proper assessment of compensation must take into account many factors including, but not limited to, those listed in the Act. This is the global approach. Section 25 (formerly s. 23) is permissive and is to be used as a guidance for the board. The section also says that the board may consider any additional factors they consider proper under the circumstances. In Norcen Energy Resources Ltd. v. Garner Lake Developments Ltd., 57 Decore J. stated that this gives "a very broad, almost infinite number of things" that the board and the court can look at.

The factors that are mentioned in the Act should be considered but common sense would require them to be considered whether the Legislature had specifically listed them or not. Furthermore, the new s. 25 makes it clear that an amount is not simply to be allocated to each subsection with a total at the end. Otherwise adding subsections (a) and (b) together would result in double compensation since they both deal with the value of the land.

How then is the value of the land to be considered in the "global appraoch"? Firstly, you must consider the marginal value of the area covered by the right of entry order as well as the average per acre value of the whole parcel: s. 25 (1) (a) and (b). Any landowner would pay a premium to acquire a small piece missing from his landholding in order to make it whole - conversely, any prospective purchaser should have to pay him a premium to persuade him to voluntarily sell it. It is this marginal value that appraisers (and the Bonaventure case) have failed to recognize.

The value of the whole parcel is also important since it is affected by the right of entry order and the operator's activities. Land, however, has no value by itself. The value of land can only be realized through its utilization. Thus, valuation must focus on the activity of using the land. The impact of the operator's activities may actually be greater on land which the appraiser considers to be less in value. It may be more difficult

56. Board Decision E 14/85 at 5 .

57. (1984) 30 L.C.R. 290 at 293. 
(and hence more costly) to repair damage to bush land or pasture land than to cultivated land. The owner may want trees in a location for a windbreak or because of the land's recreational value. The cost of replacing the tress (if possible) could easily exceed the appraiser's market value of the whole quarter section, yet the appraiser would assess compensation for each acre at $1 / 160$ of this market value!

The value of the land is therefore important in considering the loss of use, the damage and adverse effect. These factors are all inter-related and must be considered together. They are the factors that give rise to compensation rather than the value of the land itself. Appraisers, however, do not even consider damage, adverse effects, or what type of land they are dealing with once they assess market value. They assume that compensation is directly proportional to market value (i.e. the higher the market value, the higher the compensation). In fact the converse may be true. For example, appraisers give land with twelve inches of topsoil a higher market value than land with only four inches. Yet the damage caused by a wellsite on land with less topsoil will be greater because of the difficulty of restoration. Thus, tying compensation directly to market value is not accurate.

There are so many factors, tangible and intangible, to be considered that they cannot be assessed on an individual basis (apart from direct special damages such as destroyed crop). It is the combination of these factors, the synergism or the global amount that must be assessed. A farmer has to have had some experience to be aware of everything that should be considered.

A good illustration of this is found in Mobil GC v. Leighton, ${ }^{58}$ where Cawsey J. listed fifteen factors the landowner referred to in evidence which had not been considered by the appraiser.

He then went on to say: ${ }^{59}$

Leighton appeared to be a successful and knowledgeable farmer who was completely informed in modern agricultural practices. He has farmed the subject land for many years and it became very obvious that he is not the least bit happy to have the oil well on his farmland.

There are certain general principles that must be borne in mind with respect to this case. The first principle is that the original surface lease was made on the 8 th of November, 1974 and was entered into voluntarily by Leighton who agreed to accept the sum of $\$ 200.00$ per acre. However, between the date of the lease and the date of the hearing, Leighton has had the practical and actual experience of conducting his farming operations around the well, and he is now much better informed than he was on November 8 , 1974. He impressed the court with his sincerity, and he did not leave the impression that he was trying to obtain an excessive rental from the appellant. He farms this, and other land, by himself, so he has first hand knowledge of the effect of the well site on his farming operations. It was argued that in 1974 Leighton voluntarily accepted the sum of $\$ 200.00$ per acre and he could not now ask for nearly triple that amount.

I do not accept this argument. The experience gained by Leighton since 1974 was given in considerable detail, and it is apparent that the adverse effect of the area leased to the appellant on Leighton's use of the remaining land is far greater than had been contemplated.

58. Unreported, 08 October 1981, J.D. of Vegreville, Q.B. 801101082.

59. Id. at 7. 
If a landowner has experience or information from others about the impact of a wellsite, or powerline or pipeline and is reasonably informed of his rights, he can enter into negotiations with a company on a fairly even basis. Evidence of what knowledgeable farmers and companies have agreed to should be an excellent indicator of fair compensation.

It seems only logical that, if we are trying to determine the value to the owner of the rights being taken, a good indication of the value of those rights would be the price at which he or other knowledgeable owners with similar rights have agreed to dispose of them. This approach is based on the premise that a knowledgeable owner will sell his rights for a sum of money which most correctly reflects the true value of those rights to him. This is the principle in Siebens Oil \& Gas Limited v. Livingston. ${ }^{60}$

The issue of surface rights conflicts is basically one of a resource conflict, hence the "political overtones" which the Court of Appeal referred to in Siebens. According to a generally accepted principle in economics (the Coase theorem), the most efficient way to settle a resource conflict of this type is to allow for the voluntary exchange of the rights between the two parties involved. ${ }^{61}$ When the voluntary system breaks down in a particular case, the Surface Rights Act empowers the board to make the decision. The board's purpose, however, should be to approximate what willing parties would have agreed to.

It should be pointed out that the concept of a global award and the Siebens case are two different things. In fact, in Siebens the award was broken down into separate categories, presumably because of the way the case had been presented. (It is noteworthy, however, that the first category referred to in Siebens was "damage" rather than "value of the land" and the court referred to standard rates in Turner Valley in the 1930 's where compensation was dealt with in global amounts.)

Often the board does not appreciate this difference. Compensation for a right-of-entry order can only properly be expressed in terms of a global amount, whether or not there is evidence of what knowledgeable parties are agreeing to.

In Scurry Rainbow Oil Ltd. v. Lamoureaux, ${ }^{62}$ the court found that there was insufficient Siebens type evidence. Even so, Spencer J. said that the board, after evaluating the various heads of compensation: ${ }^{63}$

should then step back from its award and consider whether in its totality it gives proper compensation in any particular case. There may be some cases where the sum of the parts exceeds, and some where it falls short of proper compensation.

Assessing compensation, without evidence of comparable agreements would be extremely difficult. However if you have that evidence, it would be wrong to ignore it and, in the words of Bracco J. in the Petryshen case, ${ }^{64}$

... [to] embark on the very uncertain task of attempting to identify and evaluate the numerous factors that must be considered to determine a just compensation.

60. [1978] 3 W.W.R. 484; 15 L.C.R. 32.

61. See: R.H. Coase, "The Problem of Social Cost" (1960) 3 Journal of Law and Economics 1.

62. Unreported, 02 July 1985, J.D. of Fort St. John, S.C. 1777.

63. Id. at 8.

64. Supran. 4 at 195; 278. 
The decision of Bracco J. was approved by the Court of Appeal, where Stevenson J.A. stated: 65

A finding based on compensation for a comparable transaction does, of course, take into account residuary value because the figure is compensation for all but those items excluded under the agreement. [Emphasis added.]

In the Lamoureaux case, Spencer J. said:66

I do not think that by looking to an established pattern of value the Board necessarily abandons the criteria enjoined upon it by s. 21(1) of the British Columbia Act. It would simply be saying that the factors set out in that sub-section have historically achieved a particular pattern of value which, in an appropriate case, might be the best available evidence of the value of the right of entry under discussion.

The Eastman ${ }^{67}$ case and the Petryshen case brought the global award and the Siebens case together. In the Petryshen case, Bracco J. said:68

In any event, 1 am satisfied that full negotiations took place between Canadian Hunter and the farmers in the Elmworth agreements and 1 am prepared to accept that in such negotiations all the factors pertinent to both the pipeline company's position and the farmer's position were considered, including the residual benefits to the landowner. I therefore accept the $\$ 950$ figure as fair and acceptable compensation to both. [Emphasis added.]

He referred to the "bundle" forming the agreement, which is exactly what MacLean J. was talking about in the Eastman case. The various factors need not (and we would submit, cannot) logically be isolated.

In Eastman, MacLean J. went on to say:69

I am satisfied that under such circumstances that evidence of the so called pattern of standard rate of compensation that is being paid is the best available evidence - as to what knowledgable, experienced oil companies with all their resources and expertise, along with what knowledgable with however little experience the farmer or the owner might have, would decide as to what is a fair assessment of the compensation. It is the kind of evidence that should be given great weight - in fact, very great weight. . .

Oddly enough, however, MacLean J. in a later case, Walde v. Great Basins Petroleum Ltd., ${ }^{70}$ seemed to think that operators were being forced to pay a ransom if a negotiated amount was more than the board's calculations. He said:71

Just because the taker may be prepared to pay in blood and spades and limbs and arms and whatever, that has nothing to do whatsoever with what the value is of the interest that is being taken.

He appeared to overlook the fact that there are two parties to an agreement. The fact that the operator has reasons for reaching an agreement does not mean that the landowner would accept any less for his interest. There are pressures on the landowners to settle as well. The operators reasons do not make the agreed upon amount any less an indication of the value to the owner.

In his latest decision, Lomond Grazing Association v. PanCanadian Petroleum Ltd., ${ }^{72}$ MacLean J. reverted back to the Siebens principle. He

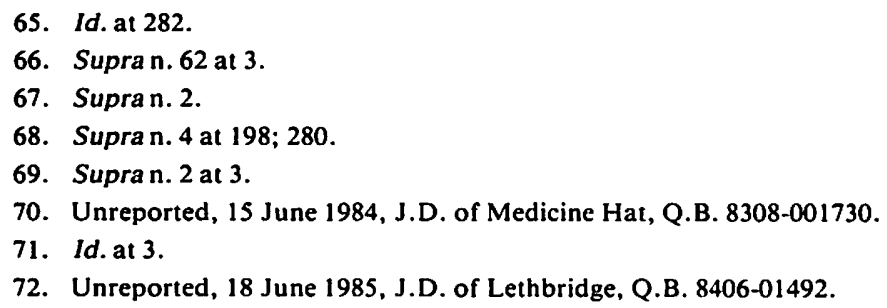


preferred the agreements presented in evidence by the owner over those of the operator because: ${ }^{73}$

\begin{abstract}
unlike the normal owner who is unsophisticated and unaware of the market value "of lands involved in surface rights proceedings" and unaware and unsophisticated in relation to the factors to be considered in determining the amount of his compensation the appellant in this case is knowledgeable and sophisticated. These appellants by reason of their knowledge and experience are able to negotiate and reach settlements based on the requirements of the Surface Rights Act and resulting in fair and meaningful compensation agreements. I am satisfied that in this case two equal competing parties met on an equal open basis and freely and voluntarily entered into a settlement unaffected by the power of complusion and expropriation and unaffected by any other extraneous factors determined only to reach settlement on the basis of an amount that represented a fair value for the rights that the operator wished to take from the owner.
\end{abstract}

He also pointed out that: ${ }^{74}$

It isn't, however, necessary to establish a pattern in order to have the evidence admissible. The pattern relates only to the weight to be given the evidence.

This proposition is important because it is sometimes suggested that the Siebens case applied a strict test. For example, in Whitehouse v. Sun Oil Company Ltd. Stevenson J.A. stated: ${ }^{75}$

The owners relied on evidence of other lease payments. Assuming that the evidence relating to other leases did meet the stringent test for the admissibility of this kind of evidence laid down in the decision of this court in Livingston v. Siebens Oil \& Gas Ltd., supra. ...

When, however, the Whitehouse case is closely examined, it will be seen that it was the attempt to isolate the various factors that once again created the problem. Stevenson J.A. acknowledge that other agreements could be looked at to assess the total compensation if the takings were comparable. Stevenson J.A. also delivered the judgment for the Court of Appeal in the Petryshen case. He upheld Bracco J.'s decision which determined compensation on the basis of what other operators were paying, not only in the immediate vicinity of the Petryshens' land, but also on a pipeline some twenty-five miles away. ${ }^{76}$ In fact, in the Siebens case, the Court admitted that "[t]here was no evidence as to how many deals were made on their land ...".77

It is submitted, therefore, that the test of the Siebens case is not overly restrictive. It requires the board, in assessing compensation, to look at agreements that are being made between landowners and operators. The board (or on appeal, the court) must determine what weight is to be given to that evidence, and if there is a pattern established for an area, the board must give this "great weight". Even an individual case can be considered, ${ }^{78}$ but, of course, less weight will be given to it. In Haukedal v. Dome Petroleum Limited, ${ }^{79}$ Decore J. held that the evidence of only an agreement in that case was not enough to overturn the board's decision. In Kerr v. Minister of Transportation, ${ }^{80}$ however, the Court of Appeal

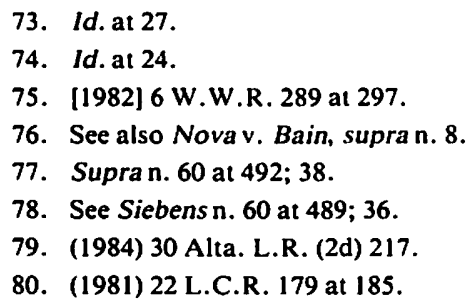


held that evidence of a mere offer made by the expropriating authority was admissible although the weight to be given to it was a matter for the Land Compensation Board.

A common criticism of the Siebens principle is that there will be no end to it, because, landowners will continue to demand more and more and the price will continue to rise. The answer, however, is obvious: once compensation is at a proper level, operators will be able to reach agreements with most landowners, and if a small number of landowners are requesting an unreasonably high amount of compensation, they will be faced with the Siebens case being used against them. In Roen v. PanCanadian, ${ }^{81}$ the board's award was reduced by the court because it was higher than what other landowners in the area had agreed to. ${ }^{82}$

The global approach was most recently endorsed by the court in Markovich Bros. Farming Co. Ltd. v. PanCanadian Petroleum Ltd. ${ }^{83}$ The board ${ }^{84}$ had attempted to distinguish the Eastman case on that basis that it dealt with a pipeline rather than a wellsite. It also stated that the failure to allocate separate amounts to the factors listed in s. 23 makes a "mockery of the Act" and "flies in the face of the Act". Decore J., however, overturned the board's decision applying the Eastman and Petryshen cases. ${ }^{85}$

In my opinion, the global approach is the better method provided some sort of cogent evidence can be produced that would allow its application. In my opinion, the strongest and most cogent evidence under which the glogal approach would be of assistance is evidence that allows what other voluntary agreements have been entered into in the area.

He relied on evidence of agreements for other well sites which were up to thirty miles away and increased the board's "four heads" compensation by approximately sixty per cent. Previous board decisions had actually relied on the same agreements to determine compensation in an area even farther away: B.P. Exploration v. Caspar, ${ }^{86}$ Forest Oil v. Parker, ${ }^{87}$ and Forest Oil v. Hagerman. ${ }^{88}$ These decisions, however, had been made by different board members than those who were sitting on the Markovich case.

Following the Court's ruling in Markovich most of the board members appeared to be generally following the global approach. For example, in Global Arctic Islands Limited v. Edey the board stated:89

The Operators position herein is to ascribe a specific dollar sum to each of the several heads of damage, and then to add these up to arrive at a total sum or sums of money as representing the payment to which the owner is entitled in compensation.

The Operator has looked at four "heads" of damage (land value, loss of use, adverse effect and general disturbance) as meriting an award in the nature of compensation.

81. Supran. 12.

82. See also as another example, Halliday Estate v. Newfoundland Light \& Power Co. Ltd. (1980) 20 L.C.R. 325.

83. (1984) 30 Alta. L.R. (2d) 211 (leave to appeal denied by the Alberta Court of Appeal).

84. Decision E. 64/83.

85. Supran. 83 at 216.

86. Decision E $67 / 82$.

87. Decision E 69/82.

88. Decision $79 / 82$.

89. Decision E233/84 at 4 . 


\begin{abstract}
Counsel for the Respondents argues a "global" sum recognizing all facets of compensation damages due the landowner, as has been negotiated by landowners and numerous other operators in the adjacent areas, produces a more equitable approach to compensation. This approach entails some adjustments, i.e., operations on home quarters and temporary camp site areas.

With respect to the Operator's position it is the Board's opinion that what the Act says at section 25 is that in determining compensation consideration shall be given to the total ef fect of the right of entry on the rights of the owner. As many of these ef fects are or may be of intangible nature which are difficult to measure other than judgmentally, the process of attaching dollar sums to each tends to become an exercise in mathematics, the result of which may or may not produce the necessary comprehensive consideration.
\end{abstract}

More recently, however, some members have broken compensation down under six or more heads and then rounded it up because as they said in Total Petroleum Canada Ltd. v. Lowe: ${ }^{90}$

There are always uncertainties inherent in estimating compensation awards where the facts are not always complete or sufficiently detailed, and the Board finds the Respondent is entitled to the benefit of any doubt or uncertainty.

\title{
IV. CONCLUSION
}

It is therefore difficult to say which approach the board will use in a particular case, but, in our view, the global approach is the most appropriate way to assess compensation under The Surface Rights Act. It follows the intent of the legislation and has been endorsed by recent decisions of the board and the courts. The best evidence of the proper level of compensation is what willing operators and landowners are agreeing to, because (as the Court of Appeal said in the Siebens case) their judgment is better than that of expert outsiders. 